\title{
Współczesne metody zarządzania czasem pracy w polskiej Policji
}

\section{Modern methods of the time management in the Polish police}

\section{Streszczenie:}

Artykuł poświęcony został problematyce zarządzania czasem pracy policjanta. Dobre gospodarowanie czasem przekłada się na lepszą organizację pracy i rozwój organizacji. Współczesne koncepcje i metody zarządzania czasem pracy w organizacji oraz odpowiednio dobrana koncepcja i metoda zarządzania czasem pracy w Policji może wpłynąć pozytywnie na skuteczność i realizacje celów statutowych oraz strategicznych. To z kolei może przynieść mierzalne oszczędności. Zwrócono również uwagę na problemy powstające $\mathrm{w}$ związku $\mathrm{z}$ interpretacją przepisów prawnych normujących czas służby policjantów, jak również na brak ustawowej definicji czasu służby.

Słowa kluczowe: czas pracy, zarządzanie czasem, modele zarządzania czasem, aspekty prawne zarządzania czasem w Policji, rozkład czasu służby.

\begin{abstract}
:
The article was devoted to the issue of time management officer. Good time management resulting in better organization of work and organizational development. Modern concepts and methods of time management in the organization and properly chosen concept and method of time management in the Police may improve efficiency and realization of statutory objectives and strategic. This in turn can produce measurable savings. Attention
\end{abstract}


Łukasz Biela - Współczesne metody zarządzania...

was also paid to the problems arising in connection with the interpretation of legal provisions regulating the time of service of police officers, as well as the lack of a statutory definition of duty.

Keywords: work time, time management, models of the time management, legal aspects of time management in the police, time distribution service.

\section{Wstęp}

$\mathrm{Na}$ przestrzeni ostatnich lat nastąpiły $\mathrm{w}$ świecie pracy zasadnicze zmiany, które w istotny sposób wpłynęły na przemiany w organizacji czasu pracy ${ }^{1}$. Czas pracy jest kategorią społeczną, ekonomiczną oraz prawną2. Stanowi ważny wyznacznik podziału zasobów czasu jednostki ludzkiej. Jest najważniejszym i niezastąpionym dobrem człowieka, które należy stale badać i kontrolować oraz chronić przed bezmyślnym marnotrawstwem ${ }^{3}$.

Czas jest jednym z najrzadszych zasobów, mającą wszechstronne zastosowanie miarą, która wykorzystywana jest do większości nakładów i efektów, jest więc miernikiem skuteczności funkcjonowania organizacji ${ }^{4}$. Czas możemy również pojmować jako zasób o charakterze nieodnawialnym, więc należy odpowiednio nim gospodarować, wdrażając do organizacji odpowiednie zasady i metody funkcjonowania5. Czas to towar deficytowy. Nie można go odzyskać, ani niczym zastąpić. Należy traktować go jako inwestycję, która przynosi zyski ${ }^{6}$. Powyższe ujęcia można uzupełnić definicją Lestera R. Bittel, który uważa, że czas jest miarą uniwersalną, może zostać użyty do większo-

\footnotetext{
${ }^{1}$ M. Morawski, Zarządzanie czasem, [w:] K. Perechuda (red.), Zarządzanie przedsiębiorstwem przyszłości. Koncepcje, modele, metody, Warszawa 2000, s. 268.

2 B. Skowron-Mielnik, Zarządzanie czasem pracy $w$ przedsiębiorstwie, Poznań 2003, s. 5 .

${ }^{3}$ H. Bieniok, Zarzq̨dzanie czasem. Nowoczesne zarzq̨dzanie $w$ biznesie, Katowice 1999, s. 7.

${ }^{4}$ P. F. Drucker, Menedżer skuteczny. Nowoczesność, Kraków 1994, s. 64-68.

5 D. Fontana, Zarządzanie czasem, Warszawa1999, s. 9-17.

${ }^{6}$ J. Adair, Anatomia Biznesu. Zarzadzanie czasem, Warszawa 2000, s. 9.
} 
ści nakładów i efektów. Autor podkreśla, że wartością związaną z czasem oraz pracą są roboczogodziny. W taki sam sposób wartościuje się produkcję organizacji liczbą wytworzonych jednostek produkcji i tak samo pracę wytworzoną przez ludzi powinno się przeliczyć na czas7. $\mathrm{W}$ obecnej chwili gospodarowanie czasem stanowi jeden $\mathrm{z}$ bardziej istotnych elementów całego procesu zarządzania. Ulepszanie jego metod prowadzi do osiągania celów osobistych i zawodowych zatrudnionych osób, co w konsekwencji wpływa na poprawę wydajności pracy danej organizacji ${ }^{8}$.

\section{Zarządzanie czasem w teorii}

Właściwości te powodują konieczność zharmonizowania różnorodnych form czasu pracy i związanych z nim zagadnień, dlatego pojawiła się nowa dziedzina nazwana zarządzaniem czasem pracy9 . Podczas przygotowania niniejszego artykułu dokonano przeglądu literatury, na podstawie której w głównej mierze wykorzystano literaturę akademicką z uwagi na niezwykle ograniczoną liczbę publikacji na temat zarządzania czasem w Policji. W literaturze przedmiotu brakuje również jednoznacznej i akceptowanej definicji pojęcia „zarządzanie czasem". Wynika to z powszechności zagadnienia oraz licznych prób definiowania przez różnych autorów. Jedna z nich określa czas pracy jako proces ściśle związany z podstawowymi cechami człowieka, regulowany przez czas zegarowy i potrzeby człowieka ${ }^{10}$. Oznacza ono podział czasu na zasadnicze obszary życia tj. na pracę, życie rodzinne, zarabianie pieniędzy, życie, stosunki z innymi ludźmi, życie umysłowe ${ }^{11}$.

\footnotetext{
${ }^{7}$ L. R. Bittel, Krótki kurs zarządzania, Warszawa-Londyn 1994, s. 251.

${ }_{8}$ T. Johns, Doskonałe zarządzanie czasem, Poznań 1999, s. 6-47.

${ }_{9}^{9}$ B. Skorwon-Mielnik, Zarzq̨dzanie czasem pracy w przedsiębiorstwie. Postawy elastycznego kształtowania czasu pracy, Poznań 2003, s. 5-6.

10 D. Fontana, Zarzadzanie czasem, Warszawa1999, s. 9-35.

11 J. Szaban, Miękkie Zarządzanie, Warszawa 2003, s. 224.
} 
Łukasz Biela - Współczesne metody zarządzania...

Z powyższym pojęciem wiążą się dwie grupy uwarunkowań, które mają wpływ na zarządzanie czasem. Pierwsza to uwarunkowania wewnętrzne, które są uzależnione od człowieka; druga grupa to uwarunkowania zewnętrzne, czyli czynniki niezależne od człowieka ${ }^{12}$. Brian Tracy zajmujący się tematyką zarządzania zasobami ludzkimi w przedsiębiorstwach oraz organizacji czasu traktuje zarządzanie czasem jako zbiór zasad dyscypliny, które, gdy zostaną opanowane umożliwiają samorealizację, osiągnięcie celów oraz życiowego sukcesu, poczucia satysfakcji i spełnienia ${ }^{13}$. Powyższe ujęcia można poszerzyć definicją Henryka Bienioka, który twierdzi, że zarządzanie czasem musi opierać się na uświadomieniu sobie, że cały kapitał to ten czas, którym dysponujemy dzisiaj ${ }^{14}$.

Natomiast Patrick Forsyth opiera zarządzanie czasem na aktywnym działaniu na rzecz wydajności i skuteczności tak, aby ułatwić osiąganie zamierzonych celów. Według autora lepsze zarządzanie czasem może ${ }^{15}$ :

- zmienić wydajność i skuteczność pracy,

- zmniejszyć presje czasu, która wiąże się z każdą pracą;

- wpływać na możliwość osiągnięcia większego sukcesu zawodowego.

Powyższe przesłanki można osiągnąć za pomocą czterech kategorii, które wprowadzają pewien ogólny ład ${ }^{16}$ :

- planowanie,

- implementacja;

- monitoringu i kontroli realizowanych zadań;

- komunikacja i kontakty z innymi w zakresie wdrażania zadań.

12 D. Antoszkiewicz, Z. Pawlak, Techniki menedżerskie: skuteczne zarzq̨dzanie fir$m q$, Warszawa 2010, s. 197-199.

13 T. Brian, Zarządzanie czasem, Warszawa 2014, s. 9-10.

14 H. Bieniok, Zarzadzanie czasem. Nowoczesne zarzadzanie $w$ biznesie, Katowice 1999, s. 23.

15 P. Forsyth, Efektywne zarzqdzanie czasem, Gliwice 2003, s. 10-11.

16 Tamże, s. 18-19. 
Reasumując, można powiedzieć słowami L. Seiwerta, że zarządzanie czasem jest konsekwentnym i zorientowanym na cel stosowaniem w praktyce sprawdzonych technik pracy w taki sposób, że kierowanie samym sobą i swoim otoczeniem odbywa się bez trudu, a otrzymany do dyspozycji czas jest wykorzystywany sensownie i optymalnie ${ }^{17}$. Autor przytacza dziesięć zalet dobrego zaplanowania i wykorzystania czasu $^{18}$.

- realizacja tych samych zadań, ale mniejszym nakładem sił,

- lepsza organizacja własnej pracy;

- lepsze wyniki w pracy;

- mniej chaosu i stresu;

- większe zadowolenie z pracy;

- większa motywacja;

- czas na realizację zadań „wyższego rzędu”;

- mniejsza presja w pracy i nacisk na wydajność;

- mniej błędów popełnianych podczas realizacji zadań;

- szybsze osiąganie celów zawodowych i prywatnych.

L. Seiwert zwraca również uwagę na tzw. „pożeraczy czasu”, które należy rozpoznać i okiełznać aby skutecznie zarządzać czasem. Wymienić ich można bardzo wiele, np.:

- nieokreślone cele działania,

- próba wykonania wielu czynności naraz;

- niewłaściwy rozkład dnia;

- nieporządek w dokumentach i terminarzach;

- niedostateczna pomoc sekretarska;

- za mało delegowania w dół;

- brak samodyscypliny;

- niedostateczna koordynacja pracy zespołowej;

- uleganie presji z zewnątrz; s. 14.

17 L. J. Seiwert, Zarządzanie czasem. Bądź panem własnego czasu, Warszawa 1998, 18 Tamże, s. 17. 
Łukasz Biela - Współczesne metody zarządzania...

- $\quad$ brak skupienia uwagi na wykonywanych czynnościach;

- niewłaściwa komunikacja w firmie;

- kultura organizacyjna sprzyjająca rozwlekaniu, przedłużaniu załatwianiu spraw;

- załatwienia spraw prywatnych w godzinach pracy;

- $\quad$ zbyt wiele czasu przeznaczonego na prace zespołowe ${ }^{19}$.

Wśród wymienionych powyżej podejść należy przytoczyć definicję Zbigniewa Pawlaka, który rozumie zarządzanie czasem poprzez planowanie, organizację, samokierowanie i kontrolę wykorzystania własnego czasu pracy ${ }^{20}$.

Według B. Clegg zarządzanie czasem jest dyscypliną, którą każdy uznaje za wartościową, a równocześnie wszyscy ja ignorują. Autor uważa, że zarządzanie czasem jest realne, że jest realne dzięki zastosowaniu błyskawicznego podejścia do problemu i dostarczenie pakietu pomysłów, które da się szybko przeczytać i szybko wprowadzić w życie 21.

Z kolei J. Szaban uważa, że w zarządzaniu czasem należy odróżnić między tym, co jest ważne, a tym, co jest pilne. Zasadnicze są te zadania, które pozwolą osiągnąć cele długoterminowe lub też takie, które mogą mieć wpływ na długofalowe konsekwencje podjętych decyzji $^{22}$. Według autora zarządzaniu czasem jest procesem systematycznym, opartym na priorytetach.

P. Drucker odnosi się do problematyki czasu, a zwłaszcza zarządzania nim poprzez trzystopniowy proces, który zawierają23:

- zapis wykorzystania czasu,

- zarządzanie czasem;

- konsolidacje czasu.

\footnotetext{
19 Tamże, s. 38.

20 D. Antoszkiewicz, Z. Pawlak, Techniki menedżerskie..., dz. cyt., s. 206.

21 B. Clegg, Błyskawiczne zarządzanie czasem, Kraków 2000, s. 1.

22 J. Szaban, Miękkie Zarządzanie, Warszawa 2003, s. 231.

23 P. F Drucker, Myśli przewodnie Druckera, Warszawa 2002, s. 346-357.
} 
Czynnikiem, który w głównej mierze wpływa na skuteczność i wyniki pracy, jest różnica pomiędzy czasem wykorzystanym i czasem zmarnowanym. Autor porusza kwestie marnotrawstwo czasu, będącego praprzyczyna niewłaściwego zarządzania nim. Według P. Druckera przyczyną marnotrawstwa czasu jest niewłaściwa funkcja informacji wewnątrz organizacji. Każda organizacja jest tym sprawniejsza, im jest prostsza bez zbędnych struktur organizacyjnych, które zniekształcają oraz wydłużają przepływ informacji.

Próba wykorzystania powyższych ujęć w zarządzaniu czasem pozwala na prawidłowe funkcjonowanie każdej jednostki organizacyjnej, nie tylko Policji. Należyte wykorzystanie zasobów ludzkich umożliwia osiągnięcie celów oraz planów strategicznych.

\section{Zarządzanie czasem w Policji}

Od momentu rozpoczęcia w Polsce przemian ekonomicznych zarządzenie w Policji ewoluuje stopniowo. Szybki rozwój gospodarki rynkowej powoduje potrzebę znalezienia skutecznej metody zarządzania $\mathrm{w}$ odniesieniu do zagadnień związanych $\mathrm{z}$ zarządzaniem czasem. Niewątpliwie zarządzanie czasem w Policji stanowi ważny problem, wymagający określenia nowych możliwości, metod i technik oraz całkowicie odmiennego podejścia do realizowanych zadań dla skutecznego funkcjonowania Policji. Zmiana metod zarządzania i organizacji pracy jest obecnie niejako wymuszana z zewnątrz przez opinię społeczną, a także od wewnątrz przez osoby zatrudnione.

Poniżej omówienie kilku koncepcji zarządzania przedsiębiorstwem, które mogą posłużyć do skutecznego zarządzania organizacją jaką jest Policja ${ }^{24}$ :

- reengineering,

- lean management,

- benchmarking,

${ }^{24}$ K. Perechuda, Metody zarządzania przedsiębiorstwem, Wrocław 1999, s. 5. 
- outsourcing,

- time based management.

Zarówno metody te, jak i współczesne koncepcje zarządzania, poprawiają skuteczność funkcjonowania każdej organizacji, należy jednak pamiętać, że nadrzędnym celem Policji jest zapewnienie skutecznej realizacji ustawowych zadań.

Jedną z koncepcji zarządzania organizacją jest reengineering. Słowo to zdobyło w ostatnim czasie bardzo dużą popularność. Ogólnie uważa się, że jest to filozofia, która ma na celu wprowadzenie usprawnień $\mathrm{w}$ realizacji pojedynczych procesów lub też całej organizacji. Metoda ta pozwala na stałe doskonalenie i usprawnienia organizacji, która nie powinna dopuścić do upadku organizacji.

Skupiając się albowiem na tym aby organizacja była nowoczesna i efektywna. Według Hammera reengineering oznacza radykalne przemyślenie i zaprojektowanie procesów, z pośrednictwem których stwarzamy wartość i wykonujemy pracę. Wymienia szybkość, jakość obsługi i koszty ogólne jako ważne elementy konkurencyjności, którymi można zajmować się w ramach reengineeringu ${ }^{25}$.

P. Grande wyróżnia cztery generalnie zasady, na których opiera się reengineering26:

- wychodzić od potrzeb klienta,

- analizować procesy w przedsiębiorstwie;

- uwzględniać istniejące ograniczenia;

- myśleć inaczej.

Specjaliści od reengineerigu sądzą, że jest on czymś więcej niż zespołem metod i technik, które są stosowane dla osiągnięcia znacznej poprawy w zakresie:

- obniżki kosztów,

- polepszenia jakości;

25 J. A. F. Stoner, R. E. Freeman, D. R. Gilbert Jr., Kierowanie, Warszawa 1999, s. 181.

${ }^{26}$ Z. Martyniak, Organizacja i Zarządzanie - 60 problemów teorii i praktyk, Kluczbork 1996, s. 322. 
- udoskonalenia szybkości działania.

Zasadniczą podstawą zastosowania tej koncepcji jest stworzenie doskonale pracującego zespołu. Taki zespół powinien tak ze sobą współpracować aby stanowił lojalną i partnerska grupę. Dąży się do stworzenia multidyscyplinarnej załogi, która łączy silne więzi i chęci odniesienia sukcesu. Kolejnym kryterium jest współpraca, którą możemy określić na podstawie częstotliwości i intensywności wymiany informacji pomiędzy członkami zespołu współpracującego.

Reengineering nie kończy się jednak zawsze sukcesem, często jego efekt jest odwrotny kończy się na rozczarowaniu. Dzieje się tak głównie z przyczyn we wprowadzaniu radykalnych zmian, jak ${ }^{27}$ :

- ludzie na ogół nie chcą zmian, boją się, stawiają opór, jest tzw. Problem socjologiczno-psychologiczny,

- błędy w budowie zespołu do reengineeringu - zespół musi być zgrany i dobrze ze sobą współpracować;

- tradycja, nawyki, przyzwyczajenia - są najtrudniejsze, bo niewidoczne.

Drugą koncepcją zarządzania jest koncepcja lean management wykorzystywaną szczególnie $\mathrm{w}$ procesie restrukturyzacji. Istotą lean management'u jest „wysmuklenie” przedsiębiorstwa poprzez wprowadzenie znaczących zmian w zakresie działalności, w strukturze majątku firmy, sposobie organizacji oraz w dziedzinie zarządzania personelem, jak też kształtowania zachowań i postaw pracowników firmy. Inicjatywa lean management'u kieruje się do uzyskania wysokiej produktywności i jakości produktów, przy maksymalnym usprawnieniu organizacji wszelkich procesów pracy. Stosowanie filozofii lean management'u pozwala prowadzić działalność gospodarczą tak, by w sposób szybki i elastyczny reagować na wyzwania zmieniającej się ekonomii. Wykorzystując różne znane techniki, a co najważniejsze - usta-

27 B. Gałka, M. Drescher, Wybrane aspekty reengineeringu w kontekście czynnika ludzkiego $w$ przedsiębiorstwie, http://www.instytutinfo/images/stories/ksiazki_polecane /16_przemiany_i_perspektywy_przedsiebiorstw_2/r28.pdf (dostęp: 29.09.2016). 
Łukasz Biela - Współczesne metody zarządzania...

nawiając nową kulturę zachowań można doprowadzić by organizacja dostosowywała się do nowych warunków w sposób naturalny i ciągły. Można to nazwać samosterującym sprzężeniem zwrotnym, bądź inteligentna organizacją28.

Lean management skupia się na realizacji czterech wzajemnie powiązanych celów, są to ${ }^{29}$ :

- krótki cykl produkcyjny,

- obniżenie kosztów operacyjnych;

- podnoszenie poziomu produkcyjnego;

- utrzymanie morale i zaangażowanie załogi.

Trzecią koncepcją zarządzania organizacją jest natomiast benchmarking. Etymologicznie wywodzi się od słowa „benchmark”, które według słownika Webstera oznacza „Punkt orientacyjny (...) oznaczający pewną pozycję (...) i używany jako punkt odniesienia (...) norma, według, której jakaś rzecz może być mierzona lub oceniana”. Dla fachowców od zarządzania benchmarking oznacza uczenie się od najlepszych poprzez porównanie z najlepszymi ${ }^{30}$.

Wyróżnia się trzy rodzaje benchmarkingu31:

- wewnętrzny,

- zorientowany na konkurencję;

- funkcjonalny.

Benchmarking wewnętrzny jest prowadzony w ramach samego przedsiębiorstwa lub sieci wzajemnie powiązanych przedsiębiorstw. Porównywane mogą być wydziały, zakłady, filie czy oddziały firmy. Benchmarking konkurencyjny to porównywanie się z organizacjami produkującymi takie same produkty lub świadczącymi podobne usłu-

${ }^{28}$ K. Zimniewicz, Współczesne koncepcje i metody zarządzania, Warszawa 2000, s. $59-61$.

${ }^{29}$ N. Kubis, Narzędzia Lean Managment, http://journals.bg.agh.edu.pl/ZAGADNIE NIA/50-2/50-2-09.pdf (dostęp: 29.09.2016).

30 J. Mioduszewski (red.), Metody organizacji i zarzq̨dzania, Olsztyn 2013, s. 231234.

${ }^{31}$ K. Zimniewicz, Współczesne koncepcje..., dz. cyt., s. 38-39. 
gi. Benchmarking funkcjonalny obejmuje analizę firm spoza sektora pod względem funkcjonalnym. Zakłada bowiem, że istnieją procesy, które niezależnie od rodzaju prowadzonej działalności, mają identyczny przebieg32.

W benchmarkingu występują następujące bariery, a mianowicie wybór odpowiedniego wzorca oraz pozyskanie wiarygodnej informacji. Z jednej strony, bariery te mogą zniechęcić do wykorzystania tej koncepcji w praktyce, z drugiej zaś strony, koncepcja ta ma również pewne zalety. Jeżeli firma jest świadoma swych niedostatków, to z pewnością będzie szukać sposobu ich przezwyciężenia. Nie musi wszystkiego robić sama, może szukać wzorców, mimo, że i one często nie są doskonałe.

Czwartą koncepcją zarządzania organizacją jest outsourcing, który według słownika zamieszczonego na stronie internetowej firmy HRK Partners - „wydzielenie realizacji różnych zadań poza obręb własnej firmy. Mianem tym bywa także określany zespół działań mających na celu wykorzystanie zewnętrznych dostawców do realizacji części celów zleceniodawcy tak, by mogli się skoncentrować na swojej podstawowej działalności (...). Outsourcing umożliwia obniżenie kosztów i płynne dostosowanie się do wahań sezonowych oraz lepsze wykorzystanie potencjału czasu, który ma do swojej dyspozycji przedsiębiorstwo ${ }^{33}$.

Ostatnią koncepcją zarządzania organizacją jest metoda Time Based Management (TBM). Metoda rozumiana jest jako koncepcja zarządzania przedsiębiorstwem, która nastawiona jest na redukcję czasu realizacji działań na poziomie operacyjnym i strategicznym. Ma stanowić przewagę konkurencyjną przedsiębiorstwa, a także musi otrzymywać priorytet w procesach zarządzania ${ }^{34}$.

32 M. Źródło-Loda, Benchmarking - Nowoczesna koncepcja zarządzania organizacja, http://www.pwsz.krosno.pl/gfx/pwszkrosno/pl/defaultopisy/1155/1/1/13.mal gorzata_zrodlo-loda_benchmarking_nowoczesna_koncepcja_zarzadzania_organizacja. pdf, s. 211-212 (dostęp: 29.09.2016).

${ }^{33}$ K. Zimniewicz, Współczesne koncepcje..., dz. cyt., s. 55.

34 J. Mioduszewski, Metody organizacji..., dz. cyt., s. 257. 
Łukasz Biela - Współczesne metody zarządzania...

Koncepcja opiera się na pięciu podstawowych elementach ${ }^{35}$ :

- orientacja na czynnik czasu,

- orientacja na skok ilościowy;

- orientacja na proces;

- orientacja na wartości;

- $\quad$ orientacja na zespół.

W koncepcji tej czas otrzymuje priorytet w procesach zarządzania, a myślenie w kategoriach czasu dotyczy wszystkich sfer działalności organizacji. Ukierunkowanie organizacji na zarządzanie czasem pracy oznacza, że w organizacji czas stawiany jest na pierwszym miejscu jako wyznacznik celu oraz bodziec do doskonalszego jej funkcjonowania $^{36}$.

Czas jest zawsze istotnym czynnikiem konkurencyjności firmy, dlatego też efektywne kierowanie przedsiębiorstwem wymaga realizowania jasnych i jednoznacznych celów oraz kontroli stopnia ich realizacji. Cele stanowią wyzwanie dla wszystkich osób i jednostek organizacyjnych zaangażowanych $\mathrm{w}$ ich realizację. Właściwe określanie celów jest bardzo ważne z punktu widzenia skuteczności zarządzania czasem pracy. Dzięki temu wiadomo, na czym należy się skoncentrować, co usprawnić i jakie są przeszkody w realizacji poszczególnych celów. Wyznaczenie celów umożliwia skoncentrowanie się na właściwych zadaniach, daje długookresową wizję i krótkookresową motywację, pomaga również zorganizować zasoby. Należy jednak pamiętać, że wyznaczane cele powinny być wyraźnie określone, krótkie oraz realistyczne i odnosić się do konkretnych zadań. Właściwe określenie celów przedsiębiorstwa leży u podstaw skutecznego zarządzania czasem pracy. Pomocne w tym mogą być następujące metody ${ }^{37}$ :

- Metoda ALPEN,

- Metoda SMART;

\footnotetext{
35 K. Zimniewicz, Współczesne koncepcje..., dz. cyt., s. 73.

36 B. Tracy, Zarządzanie czasem, Warszawa 2007, s. 29-48.

37 L. J. Seiwert, Zarządzanie czasem..., dz. cyt., s. 49-63.
} 
- Reguła 60/40;

- Zasada Pareto;

- Prawo Parkinsona;

- Zasada Eisenhowera.

Pierwszą z wymienionych metod zarządzania czasem pracy jest metoda ALPEN, która wykorzystywana jest do planowania czasu pracy w oparciu o pięć etapów tj.38:

- zestawieniu zadań,

- oceny czasu trwania określonych czynności;

- rezerwacji czasu na zajęcia nieplanowane;

- ustalaniu priorytetów, skracaniu oraz delegowaniu czynności;

- kontroli realizacji zadań.

Metoda ALPEN przynosi duże efekty przy niewielkim nakładzie czasu. Jest prosta, wydajna a jej wprowadzenie i stosowanie zajmuje niedużo czasu.

Drugim sposobem w zarządzaniu czasem jest metoda SMART. Metoda ta w literaturze jest różnie ujmowana, jednakże oznacza, że zadania jakie sobie stawiamy powinny być ${ }^{39}$ :

- szczegółowe (Specific),

- mierzalne (Measurable);

- możliwe do osiągnięcia (Attainable);

- warte nagrodzenia (Rewarding);

- ograniczone w czasie (Timely).

Pierwsze kryterium zakłada, że zadania powinny być sprecyzowane, co gwarantuje sukces i realistyczne zakończenie. Drugie kryterium zapewnia możliwość zmierzenia stopnia realizacji celu, według którego można mierzyć postęp w osiąganiu celu. Kolejnym są zadania mo-

38 J. Kobza, Magdalena Syrkiewicz-Świtała, Zarządzanie czasem w systemie opieki zdrowotnej, http://medpr.imp.lodz.pl/Zarzadzanie-czasem-w-systemie-opieki-zdrowot nej-wybrane-aspekty,546,0,2.html. pdf (dostęp: 29.09.2016).

39 J. Szaban, Miękkie Zarządzanie, dz. cyt., s. 231-232. 
Łukasz Biela - Współczesne metody zarządzania...

żliwe do osiągnięcia. Zadania muszą mieć realistyczny cel i stosowne sposoby jego wykonania. Następnym kryterium określa cele warte wynagrodzenia, istnieją jasne przesłanki dlaczego chce się je osiągnąć. Z kolei ostatnie kryterium polega na wyznaczeniu czasu na wykonanie zadania i osiągnięcie celu.

Kolejną metodą jest reguła 60/40, która jest dobrą i efektywną praktyką, pozwalającą zwiększyć swoją efektywność i produktywność. Metoda ta określa, że czas pracy powinien składać się w 60\% z czynności zaplanowanych, w 20\% z czynności nieoczekiwanych i w $20 \%$ z czynności spontanicznych. Reguła ta jest przydatna zwłaszcza dla tych, którzy nadmiernie planują, narzucając sobie dużo zadań ${ }^{40}$.

Następną metoda wspomagająca zarządzanie czasem pracy jest zasada Pareto nazwana też regułą 20/80. Zasada ta mówi, że w ciągu $20 \%$ czasu zużytego na działanie osiąga się $80 \%$ wyników. W przeciwieństwie do tego pozostałe $80 \%$ zużytego czasu przynosi tylko $20 \%$ kosztów produkcji11. W zasadzie Pareto nie zdarza się, by $100 \%$ nakładów przynosiło 100\% efektów. Kierując się tą zasadą należy wyszukiwać te czynności, które przynoszą największe efekty, czyli mniejszym wysiłkiem można osiągnąć lepsze efekty ${ }^{42}$.

Kolejną niezwykle istotną metodą wspomagającą zarządzanie czasem jest prawo Parkinsona. Metoda ta zakłada, że im więcej czasu mamy na wykonanie jakiejś pracy, tym więcej czasu nam ona zabiera. Zadanie, które należy wykonać, nabiera znaczenia i staje się bardziej złożone w prostym stosunku do czasu, który mu można poświęcić. Jeśli mamy mniej czasu, dane zadanie zrobimy znacznie szybciej ${ }^{43}$.

40 M. Znajmiecka-Sikora, Planowanie zadań czyli jak właściwie zorganizować dzień pracy, http://www.cedego. pl/czytelnia2.php?id=46 (dostęp: 29.09.2016).

${ }^{41}$ L. J. Seiwert, Zarzqqdzanie czasem..., dz. cyt., s. 131.

42 T. Urban, Zasada Pareto 80/20, http://artelis.pl/artykuly/455/Zasada-8020-za sada-Pareto.pdf (dostęp: 29.09.2016).

${ }^{43}$ A. Olejniczak, Efektywne Zarządzanie czasem - wybrane zagadnienia, MINIB Marketing Instytucji Naukowych i badawczych, nr.1 (7) marzec 2013, s. 12, http://cejsh. icm.edu.pl/cejsh/element/bwmeta1.element.desklight-7923e8e3-1333-46d3-bde7-8 ea54061bce4/c/Olejniczak_EFEKTYWNE-ZARZADZANIE-CZASEM-WYBRANE-ZAGAD NIENIA.pdf (dostęp: 29.09.2016). 
Ostatnią niezwykle istotną metodą wspomagających zarządzanie czasem jest zasada Eisenhowera. Mówi ona, że zamiast wykorzystywać czas i energię na rzeczywiście ważne sprawy jesteśmy często absorbowani przez czynności pilne, ale mniej ważne. Pierwszeństwo ustalane jest według kryteriów pilności i ważności. Zadania można zatem podzielić na 4 kategorie ${ }^{44}$ :

- zadania ważne i pilne, wymagające szybkiego działania,

- zadania ważne, ale mniej pilne, można wykonać w późniejszym terminie;

- zadania nieważne, ale względnie pilne;

- zadania nieważne i równie mniej pilne.

Wszystkie zaprezentowane metody zarządzania czasem są kluczowym elementem współczesnego zarządzania organizacją. W literaturze przedmiotu nie przeprowadzono wyczerpującej analizy metod zarządzania czasem pracy w Policji.

\section{Aspekty prawne zarządzanie czasem w Policji}

Zarządzanie czasem pracy w Policji możemy traktować jako odrębne zagadnienie. Jest to proces złożony i nie można go sprowadzić do prostego wskazania jednego czynnika. Z punktu widzenia efektywności metod zarządzania czasem pracy w jednostkach organizacyjnych Policji należy zwrócić uwagę na regulacje unijne oraz polskie rozwiązania zmierzające do dostosowania się do przepisów europejskich.

Polska na mocy tzw. Traktatu akcesyjnego w dniu 16 kwietnia 2003 roku przyłączyła się do Unii Europejskiej. Dołączenie się do struktur europejskich spowodowało konieczność dostosowania rozwiązań prawnych obowiązujących w Polsce do norm wspólnotowych. Dokonanie zmian $\mathrm{w}$ obowiązujących przepisach wynikało przede wszystkim z konieczności przyjętej dyrektywy 2003/88/WE Parlamentu Europejskiego i Rady z dnia 4 listopada 2003 roku w sprawie

${ }^{44}$ L. J. Seiwert, Zarzqdzanie czasem..., dz. cyt., s. 138-141. 
Łukasz Biela - Współczesne metody zarządzania...

niektórych aspektów organizacji czasu pracy45. Dyrektywa ma zastosowanie do wszystkich sektorów działalności, zarówno publicznych jak prywatnych w tym także Policji. Implementacja przepisów została uregulowana w art. 33 ust. 6 ustawy z dnia 6 kwietnia 1990 roku o Policji 46 oraz wydanym na jej podstawie rozporządzenia Ministra Spraw Wewnętrznych z dnia 22 września 2014 roku zmieniająca rozporządzenie w sprawie rozkładu czasu służby policjantów ${ }^{47}$. Nowelizacja doprecyzowuje, uzupełnia i ujednolica przepisy rozporządzenia Ministra Spraw Wewnętrznych i Administracji z dnia 18 października 2001 roku w sprawie rozkładu czasu służby policjantów ${ }^{48}$, a także dostosowuje je do uregulowań dyrektywy 2003/88/WE Parlamentu Europejskiego i Rady, zapewniając kompromis między prawami funkcjonariuszy a istniejącymi przepisami. Nowelizacja uwzględnia również propozycje zmian, które zostały wypracowane przez zespół powołany przez Komendanta Głównego Policji, który opracował projekt nowych rozwiązań w zakresie czasu służby policjantów ${ }^{49}$.

W obowiązującym prawie brakuje definicji „czas służby”, co sprawia, że w praktyce stosowanie przepisów powoduje szereg wątpliwości. Prawna regulacja czasu służby policjantów różni się od unormowania czasu pracy pracowników, jednocześnie wiąże się z konstytucyjną gwarancją prawa do wypoczynku ${ }^{50}$.

Definicja czasu została zawarta w art. $128 \S 1$ kodeksie pracy, w myśl której czasem pracy jest czas, w którym pracownik pozostaje do dyspozycji pracodawcy w zakładzie pracy lub innym miejscu wy-

45 Dyrektywa 2003/88/WE Parlamentu Europejskiego i Rady z dnia 4 listopada 2003 r. dotycząca niektórych aspektów organizacji czasu pracy, Dz. U. L 299 z 18.11. 2003 r., s. 9.

46 Ustawa z dnia 6 kwietnia 1990 r. z późn. zm. o Policji Dz. U. z 2011 r., Nr 287, poz. 1687 ze zm.

47 Rozporządzenie Ministra Spraw Wewnętrznych i Administracji z dnia 22 września 2014 r. w sprawie rozkładu czasu służby, Dz. U. z 2014 r., poz. 1286.

48 Rozporządzenie Ministra Spraw Wewnętrznych i Administracji z dnia 18 października 2001 r. w sprawie rozkładu czasu służby, Dz. U. Nr 131, poz. 1471.

49 Decyzja nr 610 Komendanta Głównego Policji z dnia 30 września 2008 r.

50 Konstytucja Rzeczypospolitej Polskiej z dnia 2 kwietnia 1997 r., Art. 66 ust. 2, (Dz.U. Nr 78, poz. 483 ze zm.) 
znaczonym do wykonywania pracy51. Tak więc zarządzanie czasem pracy pozostaje $\mathrm{w}$ ścisłej relacji pomiędzy stronami stosunku pracy i charakteryzuje się podporządkowaniem pracownika pracodawcy 52 .

Brak możliwości stosowania przepisów prawa pracy do warunków zatrudnienia funkcjonariuszy jest skutkiem różnego charakteru prawnego stosunków pracy i stosunku służbowego ${ }^{53}$. W obecnym stanie prawnym mamy sytuację, w której stosunki służbowe dzieli się na stosunki służbowe regulowane przez prawo pracy i stosunki służbowe będące przedmiotem prawa administracyjnego ${ }^{54}$. Stosunek służbowy policjanta charakteryzuje się dyspozycyjnością, która polega na poddaniu się szczególnej dyscyplinie służbowej. Granice tej dyspozycyjności określa ustawa o Policji i wydane na jej podstawie akty wykonaw$\mathrm{cze}^{55}$.

\section{Czas służby policjanta - podstawy prawne}

Rozkład czasu służby policjantów uregulowany jest w ustawie z dnia 6 kwietnia 1990 roku o Policji56 oraz wydanym na jej podstawie rozporządzeniu Ministra Spraw Wewnętrznych i Administracji z dnia 22 września 2014 roku w sprawie rozkładu czasu służby policjantów. Przepisy zawarte $\mathrm{w}$ wymienionych wyżej aktach prawnych maja zastosowanie do wszystkich policjantów. Rozporządzenie wprowadza zmiany polegające, że maksymalny wymiar czasu służby powinien wynosić przeciętnie 48 godzin w tygodniu w przyjętym okresie rozliczeniowym. Przekroczenie tygodniowego wymiaru czasu służby do-

51 M. Barzycka-Banaszczyk, Prawo pracy, Warszawa 2011, s. 221.

52 M. Wieczorek, Wybrane aspekty czasu służby policjantów, „Zeszyty Naukowe Uniwersytetu Przyrodniczo-Humanistycznego w Siedlcach" 2016, Nr 108, s.151-153.

53 T. Liszcz, Prawo pracy, Warszawa 2004, s. 18-19.

${ }_{54}$ T. Zieliński, Stosunek pracy i stosunek służbowy w administracji państwowej, Pracownicy administracji w PRL., J. Łętowski (red.), Wrocław 1984, s. 137.

55 Wojewódzki Sąd Administracyjny w Warszawie, wyrok z dnia 13 lutego 2007 r., IISA/Wa 2239/06, LEX nr 318269.

56 Ustawa z dnia 6 kwietnia 1990 r. o Policji, Dz. U. z 2011 r., Nr 287, poz. 1687 ze $\mathrm{zm}$. 
Łukasz Biela - Współczesne metody zarządzania...

puszczalne jest w przypadku realizacji zadań o szczególnym charakterze dla ochrony bezpieczeństwa ludzi oraz utrzymania bezpieczeństwa i porządku publicznego. Zgodnie $\mathrm{z}$ wymogami wynikającymi z § 4 ust. 4a, „w zmianowym rozkładzie czasu służby, o którym mowa w ust. 1, policjant nie może pełnić więcej niż dziesięciu służb w porze nocnej w miesiącu.". W rozporządzeniu wprowadzono dwie nowe definicje: „pora nocna” oraz „służba w porze nocnej”. Pora nocna to czas od godziny 22.00 do 6.00 , natomiast służba w porze nocnej to służba pełniona co najmniej przez trzy godziny w porze nocnej. Wydłużeniu uległ czas wolny udzielany policjantowi po takiej służbie. Nowe regulacje zostały zawarte w $\S 4$ ust. 4 zarządzenia z których wynika, że „w zmianowym rozkładzie czasu służby, o którym mowa w ust. 1, po 8 godzinach służby policjantowi udziela się co najmniej 11 godzin czasu wolnego, a jeżeli pełnił on służbę w porze nocnej - co najmniej 14 godzin czasu wolnego. Po pięciu kolejnych służbach pełnionych w porze nocnej policjantowi udziela się co najmniej 48 godzin czasu wolnego". Użyte w $§ 4$ rozporządzenia wyrazy „co najmniej" pozwalają na stwierdzenie, że należy traktować wskazany czas wolny jako niezbędne minimum odpoczynku, które powinno zostać zapewnione policjantowi. W § 4 ust. 5 zarządzenia został zwiększony wymiar czasu wolnego policjantowi, który pełnił służbę w porze nocnej w „zmianowym rozkładzie czasu służby, o którym mowa w ust. 2, po 12 godzinach służby policjantowi udziela się co najmniej 24 godzin czasu wolnego, a jeżeli pełnił on służbę w porze nocnej - co najmniej 48 godzin czasu wolnego." W obu rozkładach czasu służby o którym mowa w $\S 4$ ust. $5 \mathrm{~b}$ oraz $\S 5$ ust. $2 \mathrm{w}$ każdym tygodniu należy udzielić czasu wolnego nie krótszego niż 35 godzin. W szczególnych przypadkach czas wolny może być skrócony, nie może być jednak krótszy niż 24 godziny. W rozporządzeniu wprowadzono przepis mający na celu pełniejszą realizację prawa do wypoczynku policjantów pełniących często służby w niedziele. Zgodnie z przepisami, o których mowa w § 8 ust. 1: „Policjantowi pełniącemu służbę w niedzielę zapewnia się co najmniej raz na trzy tygodnie niedzielę wolną od służby łącznie 
z wolną sobotą albo wolnym poniedziałkiem". W § 14 ust. 2 i 3 zostały zmienione przepisy regulujące obowiązki policjanta w czasie dyżuru domowego. Policjant w czasie dyżuru powinien przebywać w miejscu zamieszkania lub w innym miejscu, z którego może w krótkim czasie stawić się w jednostce organizacyjnej Policji, w której pełni służbę. Policjant jest również obowiązany do umożliwienia przełożonemu lub upoważnionej osobie nawiązania z nim kontaktu. Z nowych przepisów wynika, że „policjant może pełnić dyżur domowy nie więcej niż 4 razy w miesiącu, w tym nie więcej niż raz w niedzielę lub święto. Czas trwania jednego dyżuru nie może przekroczyć 24 godzin, a w dniu, w którym policjant pełni służbę - 16 godzin. Czas trwania wszystkich dyżurów w miesiącu nie może przekroczyć łącznie 48 godzin". W zarządzeniu rozszerzony został katalog osób zwolnionych ze służby w porze nocnej, w niedziele i święta. W myśl § 16 ust 1 i 2 „służba w niedzielę lub święto, w godzinach zaliczanych do pory nocnej oraz w czasie przekraczającym normę określoną w art. 33 ust. 2 ustawy o Policji nie może być pełniona przez policjanta-kobietę w ciąży". Obok kobiety w ciąży i policjanta będącego jedynym opiekunem dziecka w wieku do lat 8 lub osoby wymagającej stałej opieki, ze służby takiej zwolniony zostanie również policjant opiekujący się dzieckiem do lat 8, jeżeli z uprawnienia takiego nie korzysta drugi z rodziców lub opiekun. Nowe regulacje rozszerzają kręg uprawnionych do przedłużenia czasu służby policjanta. W $\S 8$ ust. 2 uprawnienie kierownika komórki organizacyjnej, w której policjant pełni służbę, do wydania polecenia dotyczącego przedłużenia czasu służby, przysługuje również dyżurnemu jednostki. Rozporządzenie wprowadziło również zmianę polegającą na dodaniu w $§ 13$ ust. 2, zgodnie z którym rozkład czasu służby policjanta biorącego udział w akcji lub operacji policyjnej określa dowódca akcji lub operacji. Rozkład czasu służby wprowadza w podległej jednostce organizacyjnej Policji Komendant Główny Policji, Komendant Centralnego Biura Śledczego Policji, Komendant Wojewódzki, Komendant Powiatowy (Miejski) lub Rejonowy Policji, Komendant Rektor Wyższej Szkoły Policji w Szczytnie, Komen- 
dant Szkoły Policyjnej oraz Dyrektor Instytutu Badawczego. Rozkład czasu służby policjanta biorącego udział w akcji czy operacji policyjnej jest szczególnym rozkładem uzasadniającym zastosowanie odstępstwa od przepisów dyrektywy 2003/88/WE.

Niezwykle istotną zmianą jest określenie czasu przygotowania się do służby. Wprowadzenie tego przepisu wychodzi naprzeciw oczekiwaniom policjantów. Zgodnie z $§ 5$ ust. 2a rozporządzenia, Policjant ma: „czas na bezpośrednie przygotowanie do służby i jej zdanie, a w szczególności na przyjęcie lub zdanie dokumentacji z przebiegu służby, uzbrojenia i wyposażenia, wlicza się do czasu służby. Czas ten nie powinien być dłuższy niż 30 minut".

Należy zaznaczyć, że w dalszym ciągu nie uległy zmianie regulacje określające długość przerw wliczanych do czasu służby, dzień wolny lub rekompensata pieniężna za służbę pełnioną w dniu wolnym od służby oraz katalog przyczyn uzasadniających przedłużenie czasu służby policjanta. Nadal obowiązują przepisy o zmianowym czasie służby na stanowiskach, na których wymaga się pełnienia służby w systemie podstawowym, zmianowym lub w sposób ciągły.

\section{Podsumowanie}

Podstawowym wnioskiem płynącym z niniejszych rozważań jest stwierdzenie, iż Policja, jako instytucja, jest doskonałym przykładem na to, jak bardzo ważne jest zarządzanie czasem. Obecnie Policja oparta jest na hierarchicznym modelu zorganizowania opartym na systemie planowania i sprawozdawczości. Najważniejszym atrybutem przemawiającym za przeprowadzeniem zmian w Policji powinna być profesjonalna ocena potrzeb $\mathrm{w}$ tym zakresie opartym na bilansie korzyści poprzez identyfikacje jej mocnych i słabych stron wynikających $\mathrm{z}$ próby wprowadzenia bardzo nowoczesnych, sprawdzonych $\mathrm{w}$ innych organizacjach, modeli zarządzania czasem, które są bardziej skuteczne od metod, które charakteryzują się podstawowym systemem czasu pracy. Z punktu widzenia organizacji wdrożenie odpowiedniej 
metody zarządzania czasem pracy umożliwi bardziej racjonalne wykorzystanie zatrudnionych policjantów, skuteczne planowanie i organizowanie procesów pracy, ustalanie celów i zadań, jak i zarządzanie organizacją. Zastosowanie odpowiedniej metody zarządzania umożliwi również określenie oczekiwań względem poszczególnych osób i ról pełnionych przez nie w organizacji. Należy zauważyć, że Policja częściowo dostosowała przepisy do dyrektywy 2003/88WE Parlamentu Europejskiego i Rady z dnia 4 listopada 2003 r. Nadal brakuje regulacji określające długość przerw wliczanych do czasu służby, katalog przyczyn uzasadniających przedłużenie czasu służby policjanta oraz przepisy o zmianowym czasie służby na stanowiskach, na których wymaga się pełnienia służby. Dotychczasowe zmiany niektórych aspektów organizacji czasu pracy spowodowały, że policjanci zyskali prawo do wypoczynku bardzo zbliżone do tego, z jakiego korzystają pracownicy. Jednakże w dalszym ciągu brakuje definicji czasu służby, co powoduje wątpliwości w praktyce stosowania prawa. Prawna regulacja czasu służby policjantów różni się od unormowania czasu pracy pracowników. Odmienność ta znajduje uzasadnienie w specyfice stosunku służbowego, w którym pozostają policjanci. Konieczna jest nowelizacji przepisów o czasie służby policjantów, która wynika z konstytucji RP oraz konieczności dostosowania polskiego prawa do prawa wspólnotowego. Policja jako organizacja powinna wspierać nowe regulacje prawne oraz nowoczesne metody zarządzania czasem pracy co w przyszłości pozwoli czerpać korzyści z włożonego wkładu.

\section{Bibliografia:}

Adair J., Anatomia Biznesu. Zarzq̨dzanie czasem, Wydawnictwo Studio EMLA, Warszawa 2000.

Antoszkiewicz D., Pawlak Z., Techniki menedżerskie: skuteczne zarzadzanie firma, Warszawa 2010.

Barzycka-Banaszczyk M, Prawo pracy, Wydawnictwo C.H. Beck, Warszawa 2011. 
Łukasz Biela - Współczesne metody zarządzania...

Bieniok H., Zarządzanie czasem. Nowoczesne zarządzanie $w$ biznesie, Wyd. Akademii Ekonomicznej, Katowice 1999.

Bittel L. R., Krótki kurs zarządzania, PWN i McGraw-Hill, Warszawa-Londyn 1994.

Clegg B., Błyskawiczne zarzq̨dzanie czasem, IFC PRESS, Kraków 2000.

Drucker P. F., Myśli przewodnie Druckera, Wyd. MT Biznes Sp. z o.o., Warszawa 2002.

Drucker P. F., Menedżer skuteczny. Nowoczesność, Wyd. Akademii Ekonomicznej, Kraków 1994.

Fontana D., Zarządzanie czasem, PWN, Warszawa 1999.

Forsyth P., Efektywne zarządzanie czasem, Wyd. HELION, Gliwice 2003.

Gałka B., Drescher M., Wybrane aspekty reengineeringu w kontekście czynnika ludzkiego w przedsiębiorstwie, http://www.instytut.info/images/stories/ ksiazki_polecane/16_przemiany_i_perspektywy_przedsiebiorstw_2/r28. pdf.

Johns T., Doskonałe zarządzanie czasem, Wyd. Rebis, Poznań 1999.

Kobza J., Syrkiewicz-Świtała M., Zarządzanie czasem w systemie opieki zdrowotnej, http://medpr.imp.lodz.pl/Zarzadzanie-czasem-w-systemie-opieki -zdrowotnej-wybrane-aspekty,546,0,2.html.

Kubis N., Narzędzia Lean Management, http://journals.bg.agh.edu.pl/ZAGAD NIENIA/50-2/50-2-09.pdf.

Liszcz T., Prawo pracy, Wyd. LexisNexis, Warszawa 2004.

Martyniak Z., Organizacja i zarzq̨dzanie - 60 problemów teorii i praktyki, Oficyna Wydawnicza: Drukarnia Antykwa s.c., Kluczbork 1996.

Mioduszewski J. (red.), Metody organizacji i zarzqdzania, Wyd. Uniwersytetu Warmińsko-Mazurskiego, Olsztyn 2013.

Morawski M., Zarządzanie czasem, [w:] Zarządzanie przedsiębiorstwem przyszłości. Koncepcje, modele, metody, K. Perechuda (red.), Wyd. Placet, Warszawa 2000.

Olejniczak. A., Efektywne Zarzadzanie czasem - wybrane zagadnienia, http://cejsh.icm.edu.pl/cejsh/element/bwmeta1.element.desklight-7923 e8e3-1333-46d3-bde7-8ea54061bce4/c/Olejniczak_EFEKTYWNE-ZARZA DZANIE-CZASEM-WYBRANE-ZAGADNIENIA.pdf.

Perechuda K., Metody zarządzania przedsiębiorstwem, Wyd. Akademii Ekonomicznej, Wrocław 1999.

Seiwert L. J., Zarządzanie czasem. Bądź panem własnego czasu, Wyd. Placet, Warszawa 1998. 
Skowron-Mielnik B., Zarządzanie czasem pracy w przedsiębiorstwie. Podstawy elastycznego kształtowania czasu pracy, Wyd. Akademii Ekonomicznej, Poznań 2003.

Stoner J. A. F., Freeman R. E., Gilbert D. R., Kierowanie, Wyd. PWE, Warszawa 1999.

Szaban J., Miękkie zarządzanie, Wyd. Wyższej Szkoły Przedsiębiorczości i Zarządzania im. Leona Koźmińskiego, Warszawa 2003.

Tracy B., Zarzqdzanie czasem, Wyd. Muza S. A., Warszawa 2014.

Urban T., Zasada Pareto 80/20, http://artelis.pl/artykuly/455/Zasada-8020zasada-Pareto,

Wieczorek M., Wybrane aspekty czasu służby policjantów, „Zeszyty Naukowe Uniwersytetu Przyrodniczo-Humanistycznego w Siedlcach” 2016, Nr 108.

Zieliński T., Stosunek pracy i stosunek służbowy $w$ administracji państwowej, [w:] Pracownicy administracji w PRL, J. Łętowski (red.), Wyd. Ossolineum, Wrocław 1984.

Zimniewicz K., Współczesne koncepcje i metody zarządzania, Polskie Wydawnictwo Ekonomiczne S. A, Warszawa 2000.

Znajmiecka-Sikora M., Planowanie zadań czyli jak właściwie zorganizować dzień pracy, http://www.cedego.pl/czytelnia2.php?id=46.

Źródło-Loda M., Benchmarking - nowoczesna koncepcja zarządzania organizacja, http://www.pwsz.krosno.pl/gfx/pwszkrosno/pl/defaultopisy/1155 /1/1/13.malgorzata_zrodlo-loda_benchmarking_nowoczesna_koncepcja_ zarzadzania_organizacja.pdf.

\section{Akty prawne i orzecznictwo:}

Decyzja nr 610 Komendanta Głównego Policji z dnia 30 września 2008 r.

Dyrektywa 2003/88/WE Parlamentu Europejskiego i Rady z dnia 4 listopada 2003 r. dotycząca niektórych aspektów organizacji czasu pracy, Dz. U. L 299 z 18.11.2003 r.

Konstytucja Rzeczypospolitej Polskiej z dnia 2 kwietnia 1997 r. Dz. U. Nr 78, poz. 483 ze zm.

Rozporządzenia Ministra Spraw Wewnętrznych i Administracji z dnia 22 września 2014 r. w sprawie rozkładu czasu służby Dz. U. z 2014 r., poz. 1286. 
Łukasz Biela - Współczesne metody zarzq̨dzania...

Rozporządzenie Ministra Spraw Wewnętrznych i Administracji z dnia 18 października 2001 r. w sprawie rozkładu czasu służby Dz.U. Nr 131, poz. 1471.

Ustawa z dnia 6 kwietnia 1990 r. z późn. zm. o Policji Dz. U. z 2011 r., Nr 287, poz.1687 ze zm.

Wojewódzki Sąd Administracyjny w Warszawie, wyrok z dnia 13 lutego 2007 r, II SA/Wa 2239/06, LEX nr 318269. 